\title{
Damage potential of Tetranychus urticae Koch to cucumber fruit and foliage: Effect of initial infestation density
}

\author{
Kanika Tehri*, Rachna Gulati and Monika Geroh \\ Department of Zoology, CCS Haryana Agricultural University, Hisar- 125 004, INDIA \\ *Corresponding author. E-mail:knkzoology@gmail.com \\ Received: March 21, 2014; Revised received: April 22, 2014; Accepted: April 30, 2014
}

\begin{abstract}
Field trials were conducted to assess the damage potential of two-spotted spider mite (Tetranychus urticae Koch) on cucumber (Cucumis sativus Linnaeus). Young cucumber plants were artificially infested with different densities of $T$. urticae $(5,10,15$ and 20 mites/ grown up leaf) while uninfested plants acted as control. Post infestation, the plants differed in their support to mite density in accordance with initial infestation density and observation period. Grown up leaves were found to be the most susceptible to mite infestation $(5.86 \mathrm{mites} / \mathrm{sq}$. $\mathrm{cm}$ leaf). The number of feeding (chlorotic) patches on cucumber leaves significantly increased from $1.38 / \mathrm{sq} \mathrm{cm}$ at a pre -count of 5 mites per grown up leaf to $1.71 / \mathrm{sq} \mathrm{cm}$ leaf at a pre-count of 20 mites as compared to no patch recorded in control. Highly significant negative correlation was recorded between mite population and photosynthetic pigments. Total chlorophyll, chlorophyll-a, chlorophyll-b and carotenoids decreased to a maximum of $40,43.63$, 45.45 and 47.27 percent at the highest infestation density as compared to control. Results revealed differences among various treatments in terms of yield attributes of cucumber. The per cent reductions from 6.15 to 12.42 in number of fruits, 0.59 to 1.56 in fruit length and 0.93 to 3.28 in fruit width at different inoculums of $T$. urticae were recorded over uninfested plants. The cumulative effect led to the ultimate reduction in average fruit weight in the range of 10.16 to 17.19 per cent in the infested plants.
\end{abstract}

Keywords: Cucumis sativus, Chlorotic patches, Damage potential, Fruit parameters, Tetranychus urticae

\section{INTRODUCTION}

Tetranychus urticae Koch, also known as two-spotted spider mite (TSSM), is a ubiquitous and economically important agricultural pest feeding on a wide range of host plant species (Xie et al., 2006). It is probably the most important pest species in the family Tetranychidae (Meyer, 1996) and is known to attack about 1200 species of plants, of which 150 are economically important (Zhang, 2003). T. urticae is the most notorious pest responsible for significant yield losses in many economic crops, vegetables and fruit trees (Salman, 2007) and also ornamental and agronomic crops worldwide (James and Price, 2002). Cucumbers are extensively grown in India. However, its successful cultivation is threatened by a number of pests, of which $T$. urticae has achieved the major pest status (Haque et al., 2011; Dutta et al., 2012).

T. urticae has a very rapid population growth, short developmental time, high birth rate and long adult survival (Clotuche et al., 2011). The egg-adult development of female $T$. urticae is completed in approximately 6.5 days at $30^{\circ} \mathrm{C}$ (Sabelis, 1981) while the males are reported to complete development earlier than females (Mitchell, 1973). Diapausing females or eggs are the most common overwintering stage for tetranychids in response to short day lengths and cooling temperatures (Mitchell, 1973). TSSM feeds by puncturing cells with its stylets and draining the contents, thereby producing a characteristic yellow specking of the leaf surface. This chlorotic damage, alongwith the webbings produced by protonymphs, deutonymphs and adults reduces the plants' ability to carry out photosynthesis resulting in reduction of the total yield of vegetable crops. T. urticae infestation represents potential biotic stress to its host plant and heavy damage may cause leaves to dry and drop (Abdel-Wali et al., 2012). When the plant begins to decline, resulting in a reduced food supply, the mites enter a dispersal phase from sedentary phase and aggregate on the uppermost parts of the plants. Dispersal includes both intraplant and interplant movement. Aerial dispersal begins with the mites aggregating on the uppermost portions of the plants. The mites produce threads of silk, which they use to "balloon" into the wind, which sometimes carry them great distances (Smitley and Kennedy, 1985). T. urticae feeding causing aesthetic injuries as well as morphological and biochemical alterations in leaf and fruit composition has been reported earlier (Sivretepe et al., 2009; Farouk and Osman, 2012). Thus, it was decided to investigate the damage potential of $T$. urticae to foliage and yield attributes of cucumber as the foliar damage and yield loss assessment are fundamental to pest management and the means by which an organism is adjudged as a pest. 


\section{MATERIALS AND METHODS}

Raising of crop: The field trial was conducted in the Research Farm Area, Department of Entomology, CCSHAU, Hisar during 2012. Cucumber (Cucumis sativus L.) var. Damini hybrid seeds were sown in early April, 2012 and the crop was raised following standard agronomical practices. No insecticide, miticide or any other chemicals were applied to control the pest. The plants were divided into five treatment groups within a complete randomized block design consisting of ten replicates per treatment. Treatment one acted as control and consisted of plants where no mites were released. The subsequent treatments were artificially infested with $T$. urticae with the help of bird's feather pick at the density of 5, 10, 15 and 20 adult females per grown up leaf of plant, respectively.

Observations recorded: At each sampling date, T. urticae population build up (mobile stages/ $\mathrm{cm}$ leaf) on tender, grown up and older cucumber leaves (2 leaves of each stage) was recorded using hand lens. Likewise, number of chlorotic (feeding) patches per sq. $\mathrm{cm}$ on the leaves of three stages was assessed by visual count. Additionally, the number of fruits, fruit length, width and weight were also recorded. At every harvest, fruit width was assessed by using a Vernier Calliper and fruit length was measured by using a flexible tape before the fruits were weighed on a weighing balance. The experiment was continued till $T$. urticae surpassed the carrying capacity of the plants. Estimation of photosynthetic pigments: At the end of experiment (last week of sampling), leaf samples were collected per plant and the number of T. urticae per sq. $\mathrm{cm}$ leaf counted. The photosynthetic pigments were estimated as per the method of Hiscox and Israelstam (1979). Distilled water washed and finely chopped fresh leaves (excluding veins) weighing 100 $\mathrm{mg}$ were placed in a tube containing $5 \mathrm{ml}$ Dimethyl Sulfoxide (DMSO). The chlorophyll was extracted into the fluid by incubating at $65{ }^{\circ} \mathrm{C}$ for 1 hour. The extracted liquid was transferred to a $10 \mathrm{ml}$ graduated cylinder and volume was made up to the mark with DMSO. The absorbance of the colour was measured at $480 \mathrm{~nm}$ for carotenoids, 645 and $663 \mathrm{~nm}$ for total chlorophyll, chlorophyll-a and chlorophyll-b using DMSO as blank on UV-vis spectrophotometer. The concentration of total chlorophyll, chlorophyll-a, chlorophyll-b and carotenoids were calculated on fresh weight basis according to the respective formulas.

Statistical analysis: The data so obtained were analysed statistically for further interpretations. The statistical significance of data was assessed through two and three factorial analysis of variance (ANOVA). Means were then compared using Duncan's multiple range test (at $\mathrm{p}=0.05$ ) using OPSTAT software. Correlation coefficient ' $r$ ' was calculated to see the effect of mite incidence on chlorotic patches, photosynthetic pigments and yield attributes.

\section{RESULTS}

Tetranychus urticae population build up: The data pertaining to three factorial experiment (initial mite infestation $\times$ leaf age $\times$ observation period) are presented in Table 1. Statistical analysis depicted a significant effect of initial mite density on population build up of $T$. urticae on cucumber $(\mathrm{CD}=0.52$; $\mathrm{p}=0.05)$. Results revealed that maximum population developed on the plants with the highest initial infestation density of 20 mites/ grown up leaf (5.57 mites/ sq. cm leaf), followed by $4.82,4.17$ and 3.10 mites/ sq. cm leaf on plants with 15, 10 and 5 mites/ grown up leaf as the initial inoculums. When the results on population build up of $T$. urticae over weekly observations were compared, a significant effect of observation period was recorded $(C D=0.74$; $\mathrm{p}=0.05$ ) (Table 1). Irrespective of the initial inoculums, the mite number was found to significantly increase with each observation period till the attainment of peak in population on 08.06 .12 (13.62 mites/ sq. cm leaf), which afterwards showed a gradual decline to the lowest count of 0.71 mites/ sq. cm leaf as recorded on 29.06.12. However, the mite count in first two weeks was found to be at par with each other. Cucumber leaves of all ages (tender, grown up and older) were susceptible to T. urticae infestation but susceptibility was found to significantly vary with the leaf age $(\mathrm{CD}=$ $0.45 ; \mathrm{p}=0.05$ ) (Table 9). Statistically highest number of mites (5.86 mites/ sq. cm leaf) was recorded on the grown up leaves, followed by tender leaves (5.51 mites/ sq. cm leaf). However, number of mites recorded on the tender and grown up leaves were statistically at par, which can be seen with pooled means of leaves of two ages, respectively. The lowest count on the older leaves ( 2.10 mites/ sq. cm leaf) of the host plant was recovered which differed significantly with the mite count on tender and grown up leaves. Weekly observations on the population build up of $T$. urticae on cucumber revealed a significant interaction between initial mite density and observation period $(\mathrm{CD}=1.48 ; \mathrm{p}=0.05)$. At each inoculation level $(5,10,15$ and 20 mites/ grown up leaf), mite population was found to significantly increase till the attainment of peak. In the initial two weeks, the increase in mite number was statistically at par with each other in all the initial inoculums. During the last weeks of study period, plants with pre count of 15 and 20 mites dried due to T. urticae infestation.

A significant interaction between the leaf age and the initial density of mites released was obtained $(\mathrm{CD}=$ $0.90 ; \mathrm{p}=0.05)$. The interaction between observation period and leaf age was also found to be significant $(C D=1.28 ; p=0.05)$. At each observation period, the older leaves harboured minimum mite population as compared to tender and grown up leaves as can be seen by the pooled mean values. No interaction was seen between the mites released $v s$. observation period $v s$. leaf age.

Foliar damage: Cucumber leaves infested with T. urticae showed irregular pattern of chlorotic (feeding) patches as compared to healthy leaves. Data on the number of chlorotic patches formed as a result 


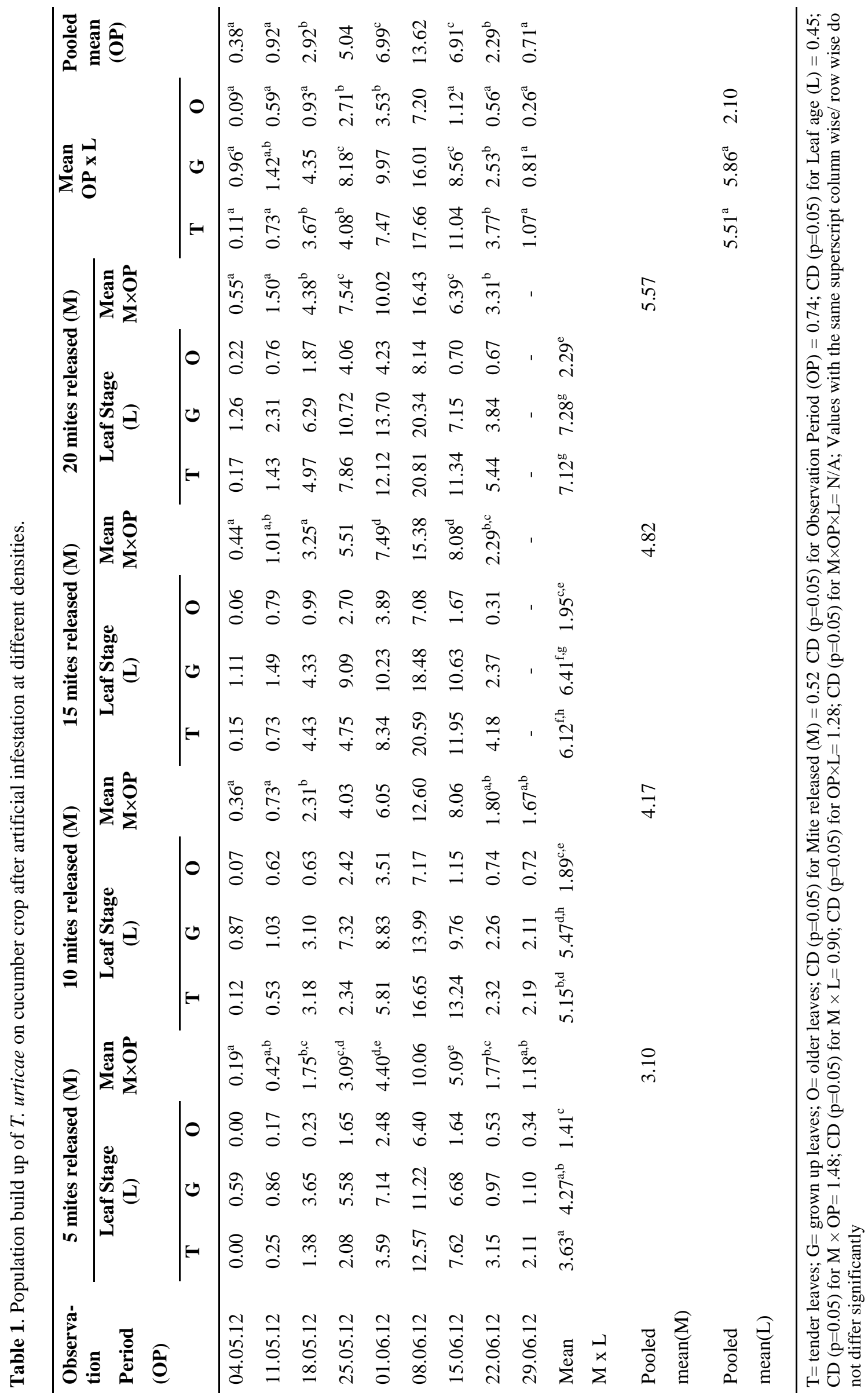


Table 2. Chlorotic patches on cucumber leaves subjected to T. urticae feeding.

\begin{tabular}{|c|c|c|c|c|c|c|c|c|c|c|c|c|}
\hline \multirow{2}{*}{$\begin{array}{l}\text { Obser- } \\
\text { vation } \\
\text { Period }\end{array}$} & \multicolumn{3}{|c|}{$\begin{array}{l}\mathrm{T} 1-5 \text { mites } \\
\text { released }\end{array}$} & \multicolumn{3}{|c|}{$\begin{array}{c}\text { T2- } 10 \text { mites } \\
\text { released }\end{array}$} & \multicolumn{3}{|c|}{$\begin{array}{c}\text { T3- } 15 \text { mites } \\
\text { released }\end{array}$} & \multicolumn{3}{|c|}{$\begin{array}{l}\text { T4- } 20 \text { mites } \\
\text { released }\end{array}$} \\
\hline & $\mathbf{T}$ & G & $\mathbf{O}$ & $\mathbf{T}$ & G & $\mathbf{O}$ & $\mathbf{T}$ & G & $\mathbf{O}$ & $\mathbf{T}$ & G & $\mathbf{O}$ \\
\hline 04.05 .12 & 0.00 & 0.00 & 0.00 & 0.00 & 0.00 & 0.00 & 0.00 & 0.00 & 0.00 & 0.00 & 0.00 & 0.00 \\
\hline 11.05 .12 & $\begin{array}{c}0.38 \\
\pm 0.18\end{array}$ & $\begin{array}{c}0.38 \\
\pm 0.18\end{array}$ & $\begin{array}{c}0.12 \\
\pm 0.08\end{array}$ & $\begin{array}{c}0.25 \\
\pm 0.16\end{array}$ & $\begin{array}{c}0.75 \\
\pm 0.16\end{array}$ & $\begin{array}{c}0.12 \\
\pm 0.06\end{array}$ & $\begin{array}{c}0.50 \\
\pm 0.16\end{array}$ & $\begin{array}{c}0.75 \\
\pm 0.22\end{array}$ & $\begin{array}{c}0.37 \\
\pm 0.18\end{array}$ & $\begin{array}{c}0.50 \\
\pm 0.18\end{array}$ & $\begin{array}{c}1.12 \\
\pm 0.12\end{array}$ & $\begin{array}{c}0.50 \\
\pm 0.18\end{array}$ \\
\hline 18.05 .12 & $\begin{array}{c}0.50 \\
\pm 0.18\end{array}$ & $\begin{array}{c}0.87 \\
\pm 0.22\end{array}$ & $\begin{array}{c}0.50 \\
\pm 0.18\end{array}$ & $\begin{array}{c}0.87 \\
\pm 0.22\end{array}$ & $\begin{array}{c}1.62 \\
\pm 0.26\end{array}$ & $\begin{array}{c}0.75 \\
\pm 0.16\end{array}$ & $\begin{array}{c}1.12 \\
\pm 0.16\end{array}$ & $\begin{array}{c}1.87 \\
\pm 0.22\end{array}$ & $\begin{array}{c}1.12 \\
\pm 0.12\end{array}$ & $\begin{array}{c}1.62 \\
\pm 0.26\end{array}$ & $\begin{array}{c}2.25 \\
\pm 0.25\end{array}$ & $\begin{array}{c}1.25 \\
\pm 0.16\end{array}$ \\
\hline 25.05 .12 & $\begin{array}{c}1.37 \\
\pm 0.18\end{array}$ & $\begin{array}{c}2.00 \\
\pm 0.19\end{array}$ & $\begin{array}{c}1.37 \\
\pm 0.17\end{array}$ & $\begin{array}{r}1.50 \\
\pm 0.18\end{array}$ & $\begin{array}{c}1.87 \\
\pm 0.22\end{array}$ & $\begin{array}{c}1.75 \\
\pm 0.16\end{array}$ & $\begin{array}{c}2.12 \\
\pm 0.22\end{array}$ & $\begin{array}{c}1.87 \\
\pm 0.22\end{array}$ & $\begin{array}{c}1.75 \\
\pm 0.16\end{array}$ & $\begin{array}{c}1.87 \\
\pm 0.12\end{array}$ & $\begin{array}{c}2.50 \\
\pm 0.18\end{array}$ & $\begin{array}{c}2.75 \\
\pm 0.18\end{array}$ \\
\hline 01.06 .12 & $\begin{array}{c}2.63 \\
\pm 0.74\end{array}$ & $\begin{array}{c}2.62 \\
\pm 0.26\end{array}$ & $\begin{array}{c}2.37 \\
\pm 0.26\end{array}$ & $\begin{array}{c}2.50 \\
\pm 0.18\end{array}$ & $\begin{array}{c}2.62 \\
\pm 0.26\end{array}$ & $\begin{array}{c}2.12 \\
\pm 0.22\end{array}$ & $\begin{array}{c}2.87 \\
\pm 0.29\end{array}$ & $\begin{array}{c}2.50 \\
\pm 0.18\end{array}$ & $\begin{array}{c}2.25 \\
\pm 0.25\end{array}$ & $\begin{array}{c}2.50 \\
\pm 0.18\end{array}$ & $\begin{array}{c}2.75 \\
\pm 0.16\end{array}$ & $\begin{array}{c}2.37 \\
\pm 0.16\end{array}$ \\
\hline 08.06 .12 & $\begin{array}{c}2.37 \\
\pm 0.18\end{array}$ & $\begin{array}{c}3.00 \\
\pm 0.19\end{array}$ & $\begin{array}{c}2.25 \\
\pm 0.16\end{array}$ & $\begin{array}{c}2.37 \\
\pm 0.16\end{array}$ & $\begin{array}{c}2.37 \\
\pm 0.18\end{array}$ & $\begin{array}{c}2.00 \\
\pm 0.18\end{array}$ & $\begin{array}{c}2.12 \\
\pm 0.12\end{array}$ & $\begin{array}{c}2.50 \\
\pm 0.18\end{array}$ & $\begin{array}{c}2.37 \\
\pm 0.18\end{array}$ & $\begin{array}{c}2.37 \\
\pm 0.18\end{array}$ & $\begin{array}{c}2.12 \\
\pm 0.29\end{array}$ & $\begin{array}{c}2.37 \\
\pm 0.18\end{array}$ \\
\hline 15.06 .12 & $\begin{array}{c}1.75 \\
\pm 0.16\end{array}$ & $\begin{array}{c}2.25 \\
\pm 0.15\end{array}$ & $\begin{array}{c}2.12 \\
\pm 0.12\end{array}$ & $\begin{array}{c}2.12 \\
\pm 0.12\end{array}$ & $\begin{array}{c}2.37 \\
\pm 0.18\end{array}$ & $\begin{array}{c}1.87 \\
\pm 0.12\end{array}$ & $\begin{array}{c}1.87 \\
\pm 0.22\end{array}$ & $\begin{array}{c}2.25 \\
\pm 0.16\end{array}$ & $\begin{array}{c}2.12 \\
\pm 0.12\end{array}$ & $\begin{array}{c}2.12 \\
\pm 0.12\end{array}$ & $\begin{array}{c}2.00 \\
\pm 0.18\end{array}$ & $\begin{array}{c}1.75 \\
\pm 0.16\end{array}$ \\
\hline 22.06 .12 & $\begin{array}{c}1.75 \\
\pm 0.25\end{array}$ & $\begin{array}{r}1.50 \\
\pm 0.19\end{array}$ & $\begin{array}{c}1.25 \\
\pm 0.16\end{array}$ & $\begin{array}{c}1.87 \\
\pm 0.12\end{array}$ & $\begin{array}{c}1.50 \\
\pm 0.18\end{array}$ & $\begin{array}{c}1.62 \\
\pm 0.18\end{array}$ & $\begin{array}{c}2.00 \\
\pm 0.18\end{array}$ & $\begin{array}{c}1.62 \\
\pm 0.18\end{array}$ & $\begin{array}{c}1.25 \\
\pm 0.16\end{array}$ & $\begin{array}{c}2.00 \\
\pm 0.18\end{array}$ & $\begin{array}{c}1.25 \\
\pm 0.18\end{array}$ & $\begin{array}{c}1.25 \\
\pm 0.16\end{array}$ \\
\hline Mean & 1.34 & 1.57 & 1.24 & 1.43 & 1.63 & 1.27 & 1.57 & 1.67 & 1.40 & 1.85 & 1.74 & 1.53 \\
\hline
\end{tabular}

$\mathrm{T}=$ tender leaves; $\mathrm{G}=$ grown up leaves; $\mathrm{O}=$ older leaves; Patches expressed as number/ sq. cm leaf (Mean \pm S.E.)

Table 3. Effect of initial infestation density of T. urticae on the chlorotic patches of cucumber leaves.

\begin{tabular}{lccccccc}
\hline Treatment & \multicolumn{2}{c}{ Tender leaves } & \multicolumn{2}{c}{ Grown up leaves } & \multicolumn{2}{c}{ Older leaves } & Mean \\
\hline & $\begin{array}{c}\text { Mite } \\
\text { no. }\end{array}$ & $\begin{array}{c}\text { chlorotic } \\
\text { patches }\end{array}$ & $\begin{array}{c}\text { Mite } \\
\text { no. }\end{array}$ & $\begin{array}{c}\text { chlorotic } \\
\text { patches }\end{array}$ & $\begin{array}{c}\text { Mite } \\
\text { no. }\end{array}$ & $\begin{array}{c}\text { chlorotic } \\
\text { patches }\end{array}$ \\
\hline T1 (no release - control) & 0.00 & 0.00 & 0.00 & 0.00 & 0.00 & 0.00 & 0.00 \\
T2 (5 mites released) & 4.37 & 1.34 & 5.15 & 1.57 & 1.87 & 1.24 & $1.38^{\mathrm{a}}$ \\
T3 (10 mites released) & 6.29 & 1.43 & 6.61 & 1.63 & 2.32 & 1.27 & $1.44^{\mathrm{a}, \mathrm{b}}$ \\
T4 (15 mites released) & 7.85 & 1.57 & 8.08 & 1.67 & 2.49 & 1.40 & $1.54^{\mathrm{b}}$ \\
T5 (20 mites released) & 9.13 & 1.85 & 9.37 & 1.74 & 2.97 & 1.53 & 1.71 \\
Correlation with mite & & 0.96 & & 0.93 & & 0.98 & \\
number & & & & & & & \\
\hline
\end{tabular}

Mite no. expressed as average no. of mites/ sq. cm leaf; Chlorotic patches expressed as average number/ sq. $\mathrm{cm}$ leaf; $\mathrm{CD}(\mathrm{p}=0.05)=0.15, \mathrm{SE}(\mathrm{m})=0.04$; Values with the same superscript do not differ significantly

of mite feeding and infestation has been presented in Table 2. At this stage, the number of chlorotic patches on leaf was $0.38,0.38$ and 0.12 on tender, grown up and older leaves, respectively at initial infestation density of 5 mites/ grown up leaf. At pre-treatment count of 10,15 and 20 mites, this number increased to 0.25 , $0.75,0.12 ; 0.50,0.75,0.37$ and $0.50,1.12,0.50$ patches/ sq. cm leaf on tender, grown up and older leaves. Thereafter, it maintained a steady appearance from third week of May to fourth week of June. The number of chlorotic patches on the leaves of cucumber was found to increase till first week of June (01.06.12). At this stage, the number recorded was 2.63, 2.62, $2.37 ; 2.50,2.62,2.12 ; 2.87,2.50,2.25$ and $2.50,2.75$, 2.37 patches/ sq. cm leaf on tender, grown up and older leaves at initial release of 5, 10, 15 and 20 mites, respectively (Table 2). Afterwards, as the duration of feeding of $T$. urticae increased, merging of chlorotic patches led to larger but decreased number of patches/ sq. cm leaf.

The data on the effect of $T$. urticae incidence on chlorotic patches showed heavy patching on tender, grown up and older leaves coinciding with the high mite initial inoculums (Table 3). Significantly higher number of chlorotic patches $(1.71 / \mathrm{sq}$. cm leaf) were recorded on the leaves of plants with the highest initial density of 20 mites/ grown up leaf $(C D=0.15 ; p=$ 0.05 ), followed by 1.54 and 1.44 patches/ sq. cm leaf when the initial infestation density was 15 and 10 mites/ grown up leaf, respectively (Table 3). Least number of chlorotic patches (1.38/ sq. cm leaf) were recorded when the initial $T$. urticae release was the lowest (5 mites/ grown up leaf). Irrespective of leaf age, statistically comparable number of chlorotic patches was formed on the leaves at an initial mite density of 5 and 10 mites/ grown up leaf. Likewise, the number of chlorotic patches formed on leaves at initial T. urticae inoculums of 10 and 15 mites/ grown up leaf did not show any significant difference with each other. A significant positive correlation between the mite population and number of chlorotic patches was obtained $(0.96,0.93$ and 0.98 on the tender, grown up and older cucumber leaves) (Table 3 ), indicating that as the initial infestation density of mites was increased; an increase in the number of chlorotic patches was observed. 
All the photosynthetic pigments (total chlorophyll, chlorophyll a, chlorophyll $\mathrm{b}$ and carotenoids) were found to be highly reduced in the infested leaves subjected to $T$. urticae feeding in accordance with the initial infestation density. As depicted in Table 4, total chlorophyll, chlorophyll a, chlorophyll b and carotenoids decreased to a maximum of $46.69,48.51$, 42.85 and 47.27 percent over uninfested leaves at highest infestation density of 20 mites. All the pigments estimated revealed a negative correlation with mite population $(r=-0.91,-0.93,-0.95$ and -0.96 , respectively), thus indicating higher loss of pigments with increasing $T$. urticae population.

Fruit damage: The fruit parameters of cucumber (fruit number/ plant, fruit length, fruit width, individual fruit weight and fruit weight/ plant) decreased with increase in initial levels of $T$. urticae infestation compared to uninfested control (Table 5). Highest infestation level of $T$. urticae caused the maximum decrease in fruit number per plant (7.11) in comparison to the lower levels of infestation and control (8.12). Different treatments led to reduction in the range of 6.15 to 12.42 percent over control in the number of fruits harvested per plant. Likewise, maximum average fruit length $(13.46 \mathrm{~cm})$ and fruit width $(4.26 \mathrm{~cm})$ was recorded from the uninfested cucumber plants. In contrast, decreased fruit length under different treatments (to the lowest of $13.25 \mathrm{~cm}$ ) and corresponding decline in fruit width (to the lowest of $4.12 \mathrm{~cm}$ ) was recorded causing upto 1.56 and 3.28 percent loss in fruit length and width, respectively. Similar trend was witnessed for the individual fruit weight. Average fruit weight declined from $147.10 \mathrm{~g}$ in control to $136.42 \mathrm{~g}$ subjected to highest initial infestation density of 20 mites contributing to 7.26 percent loss. There was a decrease in fruit weight per plant under different treatments from $1180 \mathrm{~g}$ in control to the maximum of $970 \mathrm{~g}$ at the initial infestation 20 mites causing upto 17.79 percent reduction over control.

\section{DISCUSSION}

Although all the plants supported T. urticae population build up, there was a significant variation in mite population among different treatments in accordance

Table 4. Effect of T. urticae initial infestation density on photosynthetic pigments of cucumber leaves.

\begin{tabular}{|c|c|c|c|c|c|}
\hline \multirow{2}{*}{ Treatment } & \multirow{2}{*}{ Mite No. } & \multicolumn{4}{|c|}{ Photosynthetic pigments (mg/g fresh weight) } \\
\hline & & $\begin{array}{c}\text { Total } \\
\text { chlorophyll }\end{array}$ & $\begin{array}{c}\text { Chlorophyll } \\
\mathbf{a} \\
\end{array}$ & $\begin{array}{c}\text { Chlorophyll } \\
\text { b } \\
\end{array}$ & Carotenoids \\
\hline $\mathrm{T} 1$ (no release - control) & 0.00 & 2.57 & 2.02 & 0.56 & 0.55 \\
\hline $\begin{array}{l}\mathrm{T} 2 \\
(5 \text { mites released })\end{array}$ & 13.13 & $\begin{array}{c}1.45 \\
(43.57)\end{array}$ & $\begin{array}{c}1.13 \\
(44.05)\end{array}$ & $\begin{array}{c}0.35 \\
(37.50)\end{array}$ & $\begin{array}{c}0.33 \\
(40.00)\end{array}$ \\
\hline $\begin{array}{l}\text { T3 } \\
\text { (10 mites released) }\end{array}$ & 16.48 & $\begin{array}{c}1.43 \\
(44.35)\end{array}$ & $\begin{array}{c}1.09 \\
(46.03)\end{array}$ & $\begin{array}{c}0.34 \\
(39.28)\end{array}$ & $\begin{array}{c}0.31 \\
(43.63)\end{array}$ \\
\hline $\begin{array}{l}\text { T4 } \\
\text { (15 mites released) }\end{array}$ & 19.79 & $\begin{array}{c}1.39 \\
(45.91)\end{array}$ & $\begin{array}{c}1.06 \\
(47.52)\end{array}$ & $\begin{array}{c}0.33 \\
(41.07)\end{array}$ & $\begin{array}{c}0.30 \\
(45.45)\end{array}$ \\
\hline $\begin{array}{l}\text { T5 } \\
\text { (20 mites released) }\end{array}$ & 23.36 & $\begin{array}{c}1.37 \\
(46.69)\end{array}$ & $\begin{array}{c}1.04 \\
(48.51)\end{array}$ & $\begin{array}{c}0.32 \\
(42.85)\end{array}$ & $\begin{array}{c}0.29 \\
(47.27)\end{array}$ \\
\hline $\begin{array}{l}\text { Correlation } \\
\text { with mite number }\end{array}$ & & -0.91 & -0.93 & -0.95 & -0.96 \\
\hline
\end{tabular}

Mite no. expressed as average no. of mites/ sq. cm leaf; Figures in parentheses are percent loss over control.

Table 5. Effect of initial infestation density of T. urticae on yield components of cucumber.

\begin{tabular}{lcccccc}
\hline Treatment & $\begin{array}{c}\text { No. of mites/ } \\
\text { sq cm leaf }\end{array}$ & $\begin{array}{c}\text { Fruit } \\
\text { number/ } \\
\text { plant }\end{array}$ & $\begin{array}{c}\text { Fruit } \\
\text { length } \\
(\mathbf{c m})\end{array}$ & $\begin{array}{c}\text { Fruit } \\
\text { width } \\
(\mathbf{c m})\end{array}$ & $\begin{array}{c}\text { Fruit } \\
\text { weight } \\
(\mathbf{g})\end{array}$ & $\begin{array}{c}\text { Fruit } \\
\text { weight } \\
(\mathbf{g} / \mathbf{p l a n t})\end{array}$ \\
\hline T1 & 0.00 & 8.12 & 13.46 & 4.26 & 147.10 & 1180 \\
(no release - control) & & 7.62 & 13.38 & 4.22 & 139.11 & 1060 \\
T2 & 13.07 & $(6.15)$ & $(0.59)$ & $(0.93)$ & $(5.43)$ & $(10.16)$ \\
(5 mites released) & & 7.36 & 13.35 & 4.17 & 138.94 & 1030 \\
T3 & 16.32 & $(9.35)$ & $(0.82)$ & $(2.11)$ & $(5.54)$ & $(12.71)$ \\
$(10$ mites released) & 20.49 & 7.22 & 13.29 & 4.15 & 137.11 & 990 \\
T4 & & $(11.08)$ & $(1.26)$ & $(2.58)$ & $(6.79)$ & $(16.10)$ \\
(15 mites released) & 22.18 & 7.11 & 13.25 & 4.12 & 136.42 & 970 \\
T5 & & $(12.42)$ & $(1.56)$ & $(3.28)$ & $(7.26)$ & $(17.79)$ \\
(20 mites released) & & -0.99 & -0.96 & -0.95 & -0.98 & -0.99 \\
Correlation & & & & & & \\
with mite population & & & & & & \\
\hline
\end{tabular}

Figures in parentheses are percent loss over control. 
with the initial density of mite release. The age of the leaf contributes a formidable share to the susceptibility of mite infestation and subsequent population build up. Significantly higher mite density was recorded on grown up leaves as compared to tender and older leaves of the crop. Likewise, preference of mature leaves over young leaves by $T$. urticae was also reported by Prasanna (2007) on brinjal and Geroh (2007) on okra. However, Fitzgerald et al. (2008) reported $\mathrm{T}$. urticae abundance on older leaves of strawberry while Dutta et al. (2012) reported the same in the upper canopy of brinjal. This variation in result can be explained by the fact that mites migrate from older to younger leaves when food reserve in the older leaves becomes scanty. Corroborating present results on pattern of $T$. urticae distribution on cucumber leaves, higher mite population was recorded on the ventral leaf surface as compared to the dorsal leaf surface on okra (Geroh, 2007; Nain, 2011).

Several studies have reported chlorosis as the most obvious injury symptom of leaves damaged by two-spotted spider mites and is indicative of chlorophyll loss (Reddall et al., 2004; Sivretepe et al., 2009; Farouk and Osman, 2011). The spider mite sucks the plant cell content of leaf mesophyll gradually destroying the chloroplasts. A reduction in the chlorophyll content is a primary response to spider mite infestation and has been reported in many plants including rose (Landeros et al., 2004), cotton (Reddall et al., 2004), grapevine (Sivritepe et al., 2009), tomato (Jayasinghe and Mallik, 2010) and bean (Farouk and Osman, 2011). Sivritepe et al. (2009) also reported a drastic drop in the chlorophyll content and photosynthetic rate of grapevine cultivars due to $T$. urticae feeding. Jayasinghe and Mallik (2010) recorded significant defoliation in tomato plants infested by mites for longer duration (12 or 9 weeks) and under higher mite population (400 mites per plants initially released) during early growth stages. Leaf chlorophyll content in mite infested tomato plants had significantly lower total chlorophyll $(1.592,1.597 \mathrm{mg} / \mathrm{g})$ than other feeding durations at 11 th week as compared to $1.04 \mathrm{mg} / \mathrm{g}$ after 60 days $T$. urticae feeding on cucumber leaves during present investigation. Senthil et al. (2010) reported that leaf spot disease caused by Penicillium notatum in cucumber also caused significant loss in chlorophyll-a and chlorophyll-b contents. Present study corroborated the earlier studies (Farouk and Osman, 2011) that decrease in chlorophyll-a was more pronounced than chlorophyll-b at different stages of $T$. urticae_infestation. A dramatic loss in leaf carotenoid content of bean leaves as a result of T. urticae infestation was reported by Farouk and Osman (2011), respectively.In corroboration with our studies, Landeros et al. (2004) and Geroh (2011) reported that the chlorophyll content of rose and okra plants, respectively, was negatively correlated with $T$. urticae population density. The amount and rate of change of the chlorophyll has been reported to depend on T. urticae density and duration of feeding (Alatawi et $a l ., 2007)$ and is supported in the current work.

The results on fruit damage in our investigation are in consonance with the findings of Patil (2005) on brinjal who reported 38.81 percent reduction in number of fruits and 32.21 percent reduction in yield at highest release level of $200 \mathrm{~T}$. macfarlanei per plant over control. Farouk and Osman (2011) reported significantly lower bean yield and its components i.e. pod number per plant, pod yield per plant, pod length and yield quality after artificial infestation with $T$. urticae compared to untreated controls. The present study also corroborated the earlier studies on loss of quality and quantity of harvestable material of various vegetable crops such as brinjal (Chinniah et al., 2009), tomato (Jayasinghe and Mallik, 2010) and okra (Geroh, 2011) due to T. urticae attack. Negative values of correlation coefficients depicted a reciprocal relationship between mite population and various yield components in accordance with the reports of Geroh (2011) on okra.

The major principles behind yield losses due to spider mite infestation in various crops have been established as biomass reduction, disturbance of water conduction, dry matter partitioning, $\mathrm{CO}_{2}$ gas exchange, chlorophyll reduction and shedding of immature flowers (Park and Lee, 2002). T. urticae feeding causes the destruction of chloroplasts by puncturing photosynthetically active cells (Sivritepe et al., 2009) which then leads to basic physiological changes in the plant. In gut content studies of two-spotted mites, Walsh (2001) observed the presence of only thylakoid granules, the key photosynthetic engines in plant cells, following feeding. Stomatal closure can be a primary host-plant response, and in such cases, uptake of $\mathrm{CO}_{2}$ decreases resulting in a marked reduction in transpiration as well as photosynthesis (Park and Lee, 2002; Sivritepe et al., 2009). Such leaf cell damage and tissue injury alters carbon allocation patterns of plant organs and leads to reduced yield. Earlier also, Candolfi et al. (1992) and Alawati et al. (2007) had reported decrease in assimilation of $\mathrm{CO}_{2}$ and damage to plants in proportion to mite population density and duration of feeding in accordance with our findings. The results of this study showed significant effect of feeding duration and initial infestation density of T. urticae on the foliage and yield attributes of cucumber. Mite incidence causes chlorosis in the leaves resulting in enormous loss in the total photosynthates of the plant followed by reduced yield. Thus, early identification of T. urticae incidence and implementation of treatment should minimize yield loss, allowing potential higher benefit to the growers.

\section{Conclusion}

Increased activity of $T$. urticae population was considered to play an active role in causing foliar damage and yield losses. There was a significant negative correlation between $T$. urticae infestation density and various attributes under investigation which emphasized the fact that quantitative losses occured due to T. urticae infestation in cucumber and 
as low as 5 mites released per grown up leaf (less than 1 mite/ sq. cm leaf) wass capable of causing significant damage to the crop.

\section{REFERENCES}

Abdel-Wali, M., Mustafa, T. and Al-Lala, M. (2012). Residual toxicity of abametin, milbemectin and chlorfenapyr to different populations of two-spotted spider mite, Tetranychus urticae Koch, (Acari: Tetranychidae) on cucumber in Jordan. World J. Agric. Sci., 8(2): 174-178.

Alatawi, F.J., Margolies, D.C. and Nechols, J.R. (2007). Aesthetic damage thresholds for two spotted spider mites (Acari: Tetranychidae) on impatiens: effect of plant age and level of infestation. J. Econ. Entomol., 100:1904-1909.

Candolfi, M.P., Boller, R.E. and Wermelinger B. (1992). Influence of two spotted spider mite, Tetranychusurticae, on gas exchange of Pinot noire grapevine leaves. Vitis, 31: 205-212.

Chinniah, C., Kumar, S.V., Muthiah, C. and Rajavel, D.S. (2009). Population dynamics of two spotted spider mite, Tetranychus urticae Koch in brinjal ecosystem. Karnataka J. Agric. Sci., 22: 734-735.

Clotuche, G., Mailleux, A.C., Ferna'ndez, A.A., Deneubourg, J.L. and Detrain, C. (2011). The formation of Collective Silk Balls in the Spider Mite Tetranychus urticae Koch. PLoS ONE, 6(4): 1804-1817.

Dutta, N.K., Alam, S.N., Uddin, M.K., Mahmudunnabi, M. and Khatun, M.F. (2012). Population abundance of red spider mite in different vegetables along with its spatial distribution and chemical control in brinjal, Solanum melongena L. Bangladesh. J. Agril. Res., 37(3): 399404.

Farouk, S. and Osman, M.A. (2011). The effect of plant defence elicitors on common bean (Phaseolus vulgaris L.) growth and yield in absence or presence of spider mite (Tetranychus urticae Koch) infestation. J. Stress Physio. and Biochem., 7(3): 6-22.

Farouk, S. and Osman, M.A. (2012). Alleviation of oxidative stress induced by spider mite invasion through application of elicitors in bean plants. Egyptian J. of Bio., 14: 1-13.

Fitzgerald, J., Xu X., Pepper, N., Easterbrook, M. and Solomon, M. (2008). The spatial and temporal distribution of predatory and phytophagous mites in field-grown strawberry in the UK. Exp. Appl. Acarol., 44(4): 293-306.

Geroh, M. (2007). Ecology and management of Tetranychus urticae Koch on okra, Abelmoschus esculentus L., $\mathrm{Ph}$. D. Thesis, CCS HAU, Hisar.

Geroh, M. (2011). Molecular Characterization of Beauveria bassiana (Balsamo) Vuillemin and its Bioefficacy against Tetranychus urticae Koch (Acari: Tetranychidae), Ph. D. Thesis, CCS HAU, Hisar.

Haque, M., Islam, T., Naher, N. and Haque, M.M. (2011). Seasonal abundance of spider mite Tetranychus urticae Koch on vegetable and ornamental plants in Rajshahi. Univ. j. zool. Rajshahi Univ., 30: 37-40.

Hiscox, J.D. and Israelstam, G.F. (1979). A method for extraction of chlorophyll from leaf tissue without maceration. Can. J. Bot., 57: 1332-1334.

James, D.G. and Price, T.S. (2002). Fecundity in two-spotted spider mite (Acari: Tetranychidae) increased by direct and systemic exposure to imidacloprid.. J. Econ.
Entomol., 95(4): 729-732.

Jayasinghe, G.G. and Mallik, B. (2010). Growth stage based economic injury levels for two spotted spider mite, Tetranychus urticae Koch (Acari, Tetranychidae) on Tomato, Lycopersicon esculentum Mill. Tropical Agril. Res., 22 (1): $54-65$.

Landeros, J., Guevara, L.P., Badii, M.H., Flores, A.E. and Pamanes, A. (2004). Effects of different densities of the two spotted spider mite Tetranychus urticae on $\mathrm{CO}_{2}$ assimilation, transpiration and stomatal behaviour in rose leaves. Exp. Applied Acarol., 32: 187-198.

Meyer, M.K.P.S. (1996). Mite pests and their predators on cultivated plants in southern Africa.Vegetables and berries. ARC, South Africa.

Mitchell, R. (1973). Growth and population dynamics of a spider mite Tetranychus urticae Koch, (Acarina: Tetranychidae). Ecology, 54:1349-1355.

Park, Y.L. and Lee, J.H. (2002). Leaf cell and tissue damage of cucumber caused by twospotted spider mite (Acari: Tetranychidae), J. Econ. Entomol., 95: 952-957.

Patil, R.S. (2005). Investigation on mite pests of solanaceous vegetable with special reference to brinjal. Ph.D. Thesis, University of Agricultural Sciences, Dharwad.

Prasanna, K.P. (2007). Seasonal incidence and management of tetranychid mites in brinjal. M.Sc. Thesis, University of Agricultural Sciences, Dharwad.

Reddall, A., Sadras, V.O., Wilson, L.J. and Gregg, P.C. (2004). Physiological responses of cotton to two-spotted spider mite damage. Crop Sci., 44: 835-846.

Sabelis, M.W. (1981). Biological control of two-spotted spider mites using phytoseiid predators.Part 1.Modeling the predator-prey interaction at the individual level. Agricultural Research Reports No. 910. Wageningen, Netherlands. Mitchell R (1973) Growth and population dynamics of a spider mite (Tetranychus urticae K., Acarina: Tetranychidae). Ecology, 54: 1349-1355.

Salman, M.S. (2007). Comparative toxicological studies of certain acaricides on two-spotted spider mite Tetranychus urticae Koch and its predator Stethorus gilvifrons Mulsant. Ph.D. Thesis, Plant Protection Department, Faculty of Agriculture, Suez Canal University.

Senthil, V., Ramasamy, P., Elaiyaraja, C. and Elizabeth, A.R. (2010). Some phytochemical properties affected by the infection of leaf spot disease of Cucumis sativus (Linnaeus) caused by Penicilliumnotatum. African J. of Basic and Appl. Sci., 2(3): 64-70.

Sivritepe, N., Kumral, N.A., Erturk, U., Yerlikaya, C. and Kumral, A. (2009). Responses of grapevines to twospotted spider mite mediated biotic stress. J. Biol. Sci., 9(4): 311-318.

Smitley, D.R. and Kennedy, G.G. (1985). Photo-Oriented Aerial-Dispersal Behavior of Tetranychus urticae (Acari, Tetranychidae) Enhances Escape from the Leaf Surface. Annals of the Entomol. Society of America, 78: 609-614.

Walsh, D. (2001). Spider mites-Secondary pests of Washington State wine grapes. http:/www. grapesoiety.org/2000meeting proceedings/ mtecontrol.html.

Xie, L., Miao, H. and Xiao-Yue Hong, X.Y. (2006). The two spotted spider mite Tetranychus urticae Koch and the carmine spider mite Tetranychus cinnabarinus their Wolbachia phylogenetic tree. Zoolaxa, 1166: 33-46.

Zhang, Z. (2003). Mites of Greenhouses. CABI Publishing Oxon, UK. pp. 244. 